\title{
TECNIZAÇÃO E CIVILIZAÇÃO
}

\section{TECHNIZATION AND CIVILIZATION}

\author{
Norbert Elias ${ }^{1}$ \\ ${ }^{1}$ Tradução: Regina Negri Pagani (UTFPT/UEPG) jrpagani@uol.com.br
}

\begin{abstract}
Resumo
Este artigo traz o pensamento de Elias sobre a interação que existe entre os processos de tecnização e civilização. Para ele, são ambos processos não planejados e de longa duração, sem um alvo pré-definido. O primeiro processo, de tecnização, evolui à medida que o homem trabalha em busca uma vida melhor. Neste sentido, Elias faz uma análise das invenções e descobertas feitas pelo homem, com destaque para a revolução nos meios de transporte. Ele aponta os beneficios decorrentes desta revolução, bem como os retrocessos por ela causados no processo de civilização da humanidade. Uma vez que os avanços tecnológicos são utilizados como armas de combate na busca pelo poder, estes favorecem aqueles que tem maior acesso a esses avanços, em detrimento da grande maioria da humanidade. O último processo, o civilizador, tem como premissa básica o autocontrole que, no pensamento de Elias, é condição imprescindivel para que um indivíduo possa conviver em harmonia com os demais seres humanos.
\end{abstract}

Palavras-chave: tecnização, civilização, meios de transporte, autocontrole

\section{Tecnização}

O processo de tecnização e o processo de civilização (1) são processos não planejados de longa duração movendo-se para uma direção discernível - com arrancos direcionados e não direcionados, para lá e para cá - mas sem objetivo a longo prazo. Eles são não planejados, tendo em vista que eles surgem do entrelaçar, da conjunção, da co-operação e confrontação de muitas atividades planejadas.

Tecnização é o processo pelo qual, à medida que progridem, as pessoas aprendem a explorar materiais inanimados num âmbito cada vez maior para o uso da humanidade, tratando-os e os processando, na guerra e na paz, principalmente na expectativa de uma vida melhor. Talvez muitas pessoas preferissem que eu limitasse o conceito de tecnização - e da mesma forma o conceito de tecnologia - para a época mais recente, o período no desenvolvimento da humanidade no qual as pessoas aprenderam a manipular energias inanimadas que eles mesmos tinham colocado em funcionamento como força motriz em processos industriais, produção de armamento, e equipamento 
dos mais diversos tipos. Poder-se-ia sugerir que o conceito de tecnização se limitasse ao período da máquina e assim deveria ser comparado com mecanização ou motorização; mas esta limitação dos conceitos de tecnologia e tecnização para a atualidade é vã, no sentido absoluto da palavra. Representa uma distorção egocêntrica do desenvolvimento da humanidade e obscurece a visão quanto à continuidade do processo de tecnização. Ao descobrir como fazer fogo e desfrutar do calor liberado pela queima da madeira e outros combustíveis, o homem se deparou com uma grande inovação no processo de tecnização e um grande passo para uma vida melhor em tempos de paz e (para os vitoriosos) na guerra, da mesma forma como quando aprendeu a arte de produzir veículos e aeronaves motorizados. A reconstrução do não-conhecimento é um pré-requisito essencial para entender o processo de evolução do conhecimento e do saber. Tecnização é um processo que envolve a humanidade. Desenvolveu-se lentamente no princípio, já que as pessoas conheciam relativamente pouco a cerca do mundo em que viviam, e acelerou-se com a evolução do conhecimento da natureza inanimada.

A utilização do fogo, desde o início, elevou os lucros do trabalho, reduzindo a labuta e trazendo, assim, a oportunidade de uma vida melhor (veja Goudsblom, 1987 [e 1992 - SJM]). Inovou os meios bélicos possibilitando também aos guerreiros a conquista de boas terras e alimentando esperanças de uma vida melhor. Posteriormente, o homem aprendeu a utilizar a energia nuclear, que igualmente ampliou as chances de uma vida mais produtiva. $\mathrm{O}$ fato de que eles estão se preparando para uma guerra nuclear um contra o outro, é relacionado, em parte, à natureza restrita de sua imaginação. Com que freqüência era esperada que a vitória nas guerras do passado os conduzisse a uma vida melhor? As pessoas hoje precisam compreender que mesmo a vitória produzirá uma grave conseqüência para a existência da humanidade.

Possivelmente não será entendido, imediatamente, por que eu estou falando de uma vida melhor e não de uma vida boa. A pessoa pode discutir interminavelmente sobre o significado de uma "vida boa". A expressão dá idéia de um estado absoluto e final. Representa principalmente um ideal. A expressão uma "vida melhor", por outro lado, refere-se a um processo social no desenvolvimento do qual condições de viver não se tornam boas em um senso absoluto, mas sim, em se referindo a uma fase anterior. Quando a água para lavar e cozinhar tem que ser apanhada de um poço que fica a dez minutos de distância e, mais tarde esta água pode ser encanada dentro da casa, então isso apresenta uma melhoria na vida de uma pessoa. Ela compara a fase posterior com uma anterior. Os critérios são impessoais. Pode-se falar de critérios impessoais de melhoria. A carga de trabalho pesada está reduzida quando você precisa apenas abrir uma torneira na casa para que possa ter água. Porém, se você falar de uma vida boa, então você deixa a porta aberta a qualquer capricho. 


\section{O processo civilizador}

Assim como o processo de tecnização, o processo civilizador é também um processo de aprendizagem involuntário para a humanidade. Começou nos primórdios da humanidade e continuou com muitos retrocessos até o presente momento. Não há perspectiva de fim à vista. Só a direção está clara. Neste caso, também, nossa linguagem vernacular nos pede que usemos conceitos que dão a ilusão de um estado de fim absoluto. Falemos da civilização egípcia antiga ou da civilização francesa presente. A pergunta é se e até onde há de se curvar ao uso pobre da linguagem existente. Não há nenhuma sociedade, nem indivíduos de quem a pessoa poderia dizer: "Eles são civilizados". Há, no entanto, critérios tangíveis pelos quais pode-se mostrar que algumas sociedades têm se tornado mais civilizadas, em certos aspectos, do que eram alguns séculos atrás. O processo de civilização pode ser estabelecido, inequivocamente, com a ajuda de comparações sistemáticas, ou entre fases diferentes da mesma sociedade ou entre sociedades diferentes. Mas, concebida como um estado, civilização é - em seu melhor conceito - apenas um ideal.

O processo civilizador está relacionado à aquisição de autocontrole que é imperativo para a sobrevivência de um ser humano. Sem isto um indivíduo está, irresistivelmente, à mercê da oscilação de seus próprios desejos, paixões e emoções que, sem o controle do ego, demanda satisfação imediata e causa dor, quando estes permanecem insatisfeitos. Sem que tenha aprendido a autoregular-se, um indivíduo não está na posição, sem qualquer desconforto, para adiar - conforme circunstâncias realísticas - a satisfação de seus, nem de mudar a direção em que eles são procurados. Sem autocontrole, uma pessoa é como uma criança, que ainda não é capaz de controlar seus desejos e paixões para, de fato, controlar-se a si mesma e, conseqüentemente, é incapaz de morar permanentemente na companhia de outras pessoas. O padrão de autocontrole de uma pessoa, o modo como integra e relaciona os próprios desejos aos de outras pessoas, muda em uma direção definida o curso do desenvolvimento da humanidade. O conceito de civilização refere-se propriamente à direção deste processo. $\mathrm{O}$ fato de ter uma direção discernível não significa de forma alguma que tem um propósito ou um objetivo. É, como já foi previamente dito, não planejado. Processos civilizadores e de "decivilizadores" em uma sociedade podem acontecer em sucessão variada. Em um determinado momento, eles podem compensar um ao outro, ou um deles pode prevalecer. Até aqui, numa perspectiva de longo prazo, as mudanças civilizadoras têm sido dominantes no desenvolvimento da humanidade.

A explicação para esta durabilidade na direção do processo de civilização humana requer investigação mais profunda. Minha pesquisa anterior (Elias, 1939/1994) mostrou que esta durabilidade na direção está conectada com a pacificação interna de grupos sobreviventes. Uma pacificação 
gradual, maior e mais estável nas relações sociais dentro de um grupo de pessoas, e pacificação menor entre diferentes grupos, pode ser observada em comunidades mais simples e diversificadas. Um indivíduo pode, porém, observar e facilmente demonstrar a transformação da humanidade partindo de uma figuração que inclui várias unidades de sobrevivência relativamente pequenas, através de muitas fases intermediárias (incluindo algumas reversões, como em partes da África no passado), para uma figuração que inclui um número pequeno de grandes comunidades. No curso desta transformação, o padrão gradual de pacificação - o contraste nas relações dentro e entre grupos - mudou apenas ligeiramente. Uma mudança considerável, no entanto, tomou lugar no modelo, na inspiração e nas relações dirigidas de auto-regulação na transição de um número maior de grupos pequenos para um número menor de grupos grandes. No primeiro caso, o nível de perigo no qual estes grupos e os seus membros individuais vivem, em relação ao que nós chamamos natureza não-viva e em relação a outros grupos de pessoas, é excessivamente muito maior e mais incessante que no segundo caso. A totalidade de experiência e o idioma de comunicação correspondente representam um nível mais alto de afetividade, de irrefletida egocentricidade - ou seja, de envolvimento (Elias, 1987). Manifestações de auto-controle são menos estáveis, mais marcadas por contrastes extremos e mais sujeitas a flutuações. A presente redução em nível de perigo no desenvolvimento da humanidade não é percebida freqüentemente. Alguns leitores podem se perguntar: "Como alguém pode falar seriamente de uma redução em nível de perigo quando toda a humanidade vive à sombra de uma guerra nuclear?". O fato de que as pessoas estão, nos dias de hoje, em grande perigo obscurece o horizonte. É aceito como algo absoluto. A afirmação que o perigo é grande está baseada no esforço correspondente de envolvimento - automaticamente nivelada com a afirmação de que o perigo agora é ainda maior. Mas a primeira afirmação está relacionada a um certo estado de relacionamento e é indubitavelmente verdadeira; a segunda afirmação está relacionada a um processo. Esta última afirmação precisa ser cuidadosamente verificada, confirmada ou rejeitada, sendo necessária uma visão ampla e a longo prazo e, acima de tudo, requerendo uma reconstrução do não-conhecimento - ou seja, da posição na qual as pessoas se achavam no passado e, em parte, ainda se encontram hoje. Na realidade, pessoas que viviam em pequenas comunidades eram freqüentemente rodeadas por seres humanos hostis e animais selvagens. Também foram particularmente expostas aos perigos de eventos naturais imprevisíveis - a imprevisibilidade era proporcional ao limite de seus conhecimentos - e eram incomparavelmente mais desprotegidos do que, atualmente, as pessoas nos países mais desenvolvidos.

Nesta última afirmação, viver juntos em uma área relativamente pacificada com um número comparativamente muito grande de pessoas demanda um equilíbrio relativamente alto, estabilidade e variedade de autocontrole adquirido. É a maior diversidade, extensão e variedade das cadeias de interdependência que passam através da existência social de um indivíduo que as cria como questões 
importantes no curso dos acontecimentos. Se alguém considera a direção do até então não planejado processo civilizador e se pergunta como isto poderia ser incorporado a um conjunto de metas para o futuro, este alguém poderia formulá-las como segue: essencial ao conceito de civilização é um autocontrole de pessoas crescente e equilibrado, individualmente, em sua vida social que aumentarão as chances de prazer na vida, na qualidade de vida para cada participante e, finalmente, para toda a humanidade.

\section{Tecnização e Civilização}

O título de meu artigo é "Tecnização $\underline{e}$ Civilização". Esta é a forma atual de criar título de artigos: pegue dois nomes e una-os com uma palavra minúscula $\underline{e}$. Parece tão inofensiva esta palavra minúscula. Você tem que se precaver de sua simplicidade aparente. É danosa e extremamente incerta. Pois, que tipo de relação, de fato, há entre tecnização e civilização? Assim o é entre mesa e cadeira, ou entre causa e efeito? Mas os dois processos simplesmente não existem lado a lado de tal modo que um possa ser inserido no outro. Nem é obviamente o caso de que tecnização seja causa e civilização efeito - ou vice-versa. Ambos, de fato, têm continuado, bem como as espécies presentes de seres humanos. Até mesmo inventar a ferramenta de pedra mais simples era baseado, como todas as outras técnicas, na habilidade humana específica de colocar à parte, durante algum tempo, o desejo de satisfazer uma necessidade ou emoção e utilizar esta pausa para outras atividades. Estas atividades, sem contribuir diretamente para a satisfação ao término da pausa interposta - o desvio por alienação - promete ao final uma certeza maior de uma melhor gratificação aos desejos adiados. Mas se os primeiros passos em direção à tecnização já presumiram a habilidade em conter um desejo, adiar um prazer insinuando, em resumo, o auto-controle dos seus desejos - então este auto-controle do ego, esta restrição, este adiamento temporário também estava baseado na promessa de prazer para vir e a expectativa que os desejos realmente encontrariam satisfação. Certamente o ato de negar-se a um desejo durante a pausa exigia sua recompensa por uma gratificação liberal e, se possível, mais extravagante e maior dos desejos de alguém do que teria sido possível sem o desvio por alienação.

$\mathrm{O}$ indivíduo se dá conta, até mesmo durante uma primeira tentativa para descobrir o que realmente está por trás da palavra minúscula $\underline{e}$ no tema "Tecnização e Civilização", que a estrutura tradicional de conceitos é insatisfatória para o seu uso em sociologia. A relação entre dois processos humanos interconectados que não têm nenhuma origem (da mesma maneira que humanidade não tem nenhum) não se ajusta no esquema tradicional de uma relação causal a curto prazo que sempre presume uma origem e desta maneira, desde o princípio, um mundo descontínuo (Elias, 1987).

Tecnização e civilização são apenas dois dos muitos fios entrelaçadas do desenvolvimento da 
humanidade. Eu, certamente, não considero um dos dois como a base e o outro como a superestrutura, ou um como a causa e o outro como o efeito. Este não é o caso. Há muito tempo atrás era difícil imaginar que o sol, as estrelas e a terra não estivessem em fundações sólidas, e que eles eram, por assim dizer, "livremente suspensos no espaço". Da mesma maneira é aparentemente ainda difícil hoje para as pessoas imaginarem que a humanidade se desenvolveu sem haver uma única esfera básica - e, mais ainda, em todas as vezes a mesma esfera básica - formando a fundação cujo desenvolvimento impulsiona o desenvolvimento de todas as outras esferas como um tipo de força motriz auto-ativa, e de fato também serve como uma medida para isto. O entrelaçamento destas "esferas" é realmente um problema complexo. Mas a visão de um indivíduo é obscurecida pela necessidade de achar origens. Não há nenhuma esfera fundamental no desenvolvimento da humanidade que forma a base para todas as outras. O Alfa e o Omega deste desenvolvimento são os seres humanos - ou mesmo a própria humanidade.

\section{A tecnização do transporte}

Como pode um indivíduo manter este tema extenso dentro dos limites sem perder de vista os problemas teóricos básicos? Eu acredito que isto é possível se eu tratar um desenvolvimento tecnológico definido, um exemplo no processo de tecnização em detalhe relativamente maior. Deixeme usar algum material empírico atual para mostrar como tecnização e civilização interagem. $\mathrm{O}$ exemplo que eu desejo utilizar, as transformações nos meios de transporte desde o século dezenove, é um exemplo de uma inovação surpreendentemente rápida da humanidade em uma dimensão nova, dentro dos novos moldes de vida social e, não menos, em um novo nível de civilização. Uma inovação, porém, não deve ser confundida como sendo o estágio conclusivo do que foi inovado. Nós ainda estamos em um processo de aprender a lidar com os vários problemas da inovação.

Permita-me primeiramente abordar o problema da inovação do ponto de vista do processo de tecnização. A transformação radical alcançada no transporte de mercadorias e pessoas foi uma das maiores mudanças científico-tecnológicas, e de mais de longo alcance, que aconteceu nos séculos dezenove e vinte. Esta revolução do transporte foi um processo em que todas as fases ocorreram na mesma direção: a direção de mobilidade crescente e distâncias decrescentes sobre a terra, e agora no que nós livremente chamamos espaço. Isto é um processo social não planejado, assim como outros processos semelhantes, surgiu do efeito do entrelaçar de muitas atividades individuais reforçando e, ao mesmo, combatendo uns aos outros. Do ponto de vista do medíocre, absorvido em suas próprias

atividades individuais, o caráter dramático da situação quase não é notado. É preciso recuar, para alcançar uma síntese de um ângulo mais alto de visão, a fim de observar o processo não planejado em 
toda a sua magnitude, a fim de entender os problemas que surgem quando o indivíduo está frente a frente com um processo que já dura há séculos, como o problema de por quê se manteve em uma direção constante. O que foi que guiou os seres humanos por gerações, particularmente nos séculos dezenove e vinte, para concentrar sua capacidade de pesquisa científica, entre outras coisas, em aumentar sua própria mobilidade, na aceleração do transporte?

Para os que já sabem, é um método útil de investigação começar por reconstruir, para seu próprio entendimento, a situação que fez decolar todo o processo, o estado do não-conhecimento.

A força motriz mais comum no transporte até o começo do século dezenove era o poder dos músculos, humano ou animal. Forças motrizes adicionais disponíveis aos seres humanos eram os dois elementos naturais que tinham, até então, sido aproveitado por eles - as forças do vento e da água.

O processo social de revolução no transporte estava muito intimamente ligado a uma não tão marcante revolução no desenvolvimento do conhecimento humano. Seres humanos obtiveram sucesso quebrando os laços que prendiam seus meios de mobilidade às forças motrizes, as quais com maior ou menor utilização que os elementos naturais tinham colocado à sua disposição. No lugar destas forças naturais, eles próprios produziram novas formas de poder motriz para o equipamento mecanizado mais diverso, inclusive equipamento para transporte, através do processamento de materiais naturais. Estas formas motrizes humanamente elaboradas eram muito mais controláveis pelo homem e também mais duráveis e, eventualmente, mais fortes que o poder dos músculos ou vento e água. Pelo menos, as pessoas poderiam aprender como controlar estas forças. As quatro fases da revolução no transporte pelo homem no século dezenove e vinte são certamente bem conhecidas:

1. a fase da máquina a vapor, com a estrada de ferro em terra e o navio a vapor em água;

2. a fase dos veículos motorizados;

3. a fase do aeroplano;

\section{4. a fase de veículos espaciais e do poder nuclear.}

Se você recuar a fim de ter uma visão melhor de todas estas mudanças radicais juntas ocorridas no transporte por duzentos anos ou mais, não perguntará a si mesmo como a constância na direção deste desenvolvimento revolucionário por gerações pode ser explicada?

Eu posso apenas propor a pergunta, e usar um exemplo para mostrar que uma preocupação com processos sociais de longa duração - usando uma abordagem de processo sociológico para um problema - ajuda a fazer o não-óbvio sobressair-se mais nitidamente que o óbvio. Pode então ser visto, comparando-se as quatro fases, que cada uma destas quatro inovações tecnológicas não foi simplesmente um caso isolado de invenção em um período, mas também em si mesmo inovador em seu caráter; cada uma das quatro fases era um processo social no qual pode-se distinguir um período de experimentação, de ainda não-conhecimento, de riscos e perigos; e um período, de 
amadurecimento, de aprimoramento (eu ainda não consigo achar nenhuma palavra melhor para estes conceitos). Sociologicamente mais relevante é o fato de que a experimentação tecnológica muito cedo caminhe de mãos dadas com experimentos ligados a formas relevantes de organização social.

Para o propósito deste artigo eu terei que me limitar a uma consideração um pouco superficial de duas destas fases: o desenvolvimento do automóvel e o desenvolvimento do aeroplano. Isto bastará para mostrar algumas das conexões entre os processos de tecnização e civilização. Eu gostaria de apresentar primeiro algum material ilustrativo relativo ao período experimental no desenvolvimento do automóvel.

Nós normalmente não perguntamos quem de fato inventou o automóvel. Esta realmente é uma falsa maneira de apresentar o problema. Pois, ao invés de um inventor, achamos um processo inicialmente difuso e mais tarde crescentemente concentrado - de experimentação que durou aproximadamente cem anos.

Tentativas para desenvolver veículos automotores de auto-estrada eram feitas, até onde pode ser visto, quase ao mesmo tempo em que as tentativas bem sucedidas para desenvolver trens movidos a vapor. Mas eles objetivavam desenvolver um sucessor motorizado para as carruagens particulares para carregar seus donos para onde quer que fossem. Isto era, aparentemente, tecnologicamente, muito mais difícil do que desenvolver um trem movido a vapor colocado firmemente sobre seus trilhos, e que carregaria seus passageiros não de porta em porta, mas de uma estação de trem a outra. $O$ Parlamento Britânico aprovou uma lei em 1835 que tentava regular o volume constantemente crescente de tráfego nas principais estradas rurais da Inglaterra, um tipo de "Código de Rodovia". Um dos regulamentos dizia respeito aos futuros usuários dos modernos veículos automotores. A julgar por esta lei pode ser deduzido que aquelas carruagens sem cavalos não foram vistas como formas primitivas de uma tecnologia com um grande futuro, mas antes muito mais como monstruosidades perigosas. A lei de 1835 estabeleceu como velocidade máxima permitida 4 milhas inglesas por hora para veículos automotores. Decretou também que cada um daqueles meios de transporte sem cavalo deveria ser precedido por um homem empunhando uma bandeira vermelha, aparentemente para alertar veículos movidos à tração animal e pedestres que poderiam estar se aproximando. Este regulamento só foi revisado pelo Parlamento em 1896. Uma nova lei estabeleceu então um novo limite de velocidade de 10 milhas por hora. $\mathrm{O}$ regulamento que exigia que um homem, com uma bandeira vermelha, teria que caminhar à frente também parece ter sido derrubado (2). Uma nova lei determinando a velocidade máxima de 20 milhas por hora foi então estabelecida para a Inglaterra em 1903. Em 1930 o Parlamento aboliu a velocidade máxima para carros privados e motocicletas. Porém, os acidentes aumentaram a uma tal extensão que um novo limite de velocidade foi reintroduzido nas áreas urbanas.

Para todo o espalhafato e aborrecimento, este novo meio de transporte se tornou o centro de um 
longo processo de aprendizagem. Revelou possibilidades antes nunca sonhadas e, ao mesmo tempo, perigos imprevisíveis. Pôs em movimento, como veremos, um impulso do processo civilizador. Na realidade foi o próprio produto de tal impulso que ao mesmo tempo provocou outro impulso na direção oposta, um movimento para a decivilização. Visto em termos do conceito teórico de civilização, o automóvel teve duas faces.

Nosso próprio processo de aprendizagem, processo de aprendizagem como sociólogos, torna necessária a criação de uma ferramenta conceitual para compreender tais processos de aprendizagem tecnológicos de longo prazo como, por exemplo, o processo do desenvolvimento do veículo automotor. A convenção faz-nos investigar, como um assunto de rotina, o inventor individual de inovações tecnológicas como o carro automotor ou o aeroplano. Porém, a confrontação com a evidência nos força a desistir deste tipo de questionamento. Muitas pessoas tentaram isto. Eles experimentaram esperançosamente. Alguns tiveram êxito. E então outros até mesmo fizeram melhor. É para isto que os sociólogos tentam apontar, quando afirmamos que a explicação para inovações tecnológicas, como o automóvel ou o avião, não podem ser achadas em um único inventor, mas em um processo social. Contudo, esta expressão não significa que este é um processo que ocorreu fora e além do individual. Simplesmente significa que esta inovação origina-se dos esforços de muitas pessoas, enquanto trabalhando a favor e ao mesmo tempo contra umas às outras, as quais estão aprendendo isoladamente e junto com suas tentativas, fracassos e sucessos parciais, de forma que o avanço e a última inovação para uma inovação útil surgem fora do entrelaçar de muitos passos pequenos, muitas vitórias pequenas e derrotas, freqüentemente estendendo-se por várias gerações, conduzindo à solução do problema. O problema sociológico proposto pelo desenvolvimento de tais inovações sociais é diferente do - até agora bastante rotineiro - problema histórico que focaliza o inventor individual. Propor a questão sociológica significa que atenção tem que ser dada ao desenvolvimento social global responsável por casos como o veículo automotor ou o aeroplano, onde a experimentação desorganizada e, de certo modo, difusa por várias pessoas, dirige lentamente o conhecimento humano suficientemente longe para permitir uma solução prática para o problema da sociedade. Talvez seja útil distinguir entre um período preparatório de experimentação, um período de um avanço encorajador mútuo entre experiência e fracasso e um período de maturidade. Neste último, a estrutura básica da inovação tecnológica desejada é achada, e de lá então segue um período prolongado de maior desenvolvimento para melhorar a estrutura inicialmente bem básica.

No caso do automóvel, este ponto de transição do período experimental "tentativa e erro" para o período de maturidade, foi alcançado por volta de 1885/86. As honras pela invenção do primeiro carro automotor utilizável é normalmente compartilhado entre os dois alemães Gottlieb Daimler e Karl Benz. O trabalho pioneiro, porém, rapidamente passou para a França onde, por exemplo, a 
Renault mostrou rápidos avanços. Até mesmo hoje, palavras originalmente francesas tais como “chauffer", "garage”, e claro “automobile”, são remanescentes da influência primitiva da França. Dois irmãos, Charles e Frank Duryea, são conhecidos como os primeiros americanos que apresentaram a público um carro automotor utilizável (Lacey, 1986: 36). Depois da inovação, a expansão acelerou-se. A fim de entender o processo de desenvolvimento e também nossos problemas presentes, pode ser útil apresentar alguns dados estatísticos, trazendo à luz quase cem anos atrás. O Chicago Times Herald organizou a primeira corrida de carros automotores. Aconteceu em 1895. O curso, mais de 52 milhas, foi completado sob uma nevasca por apenas dois dos seis competidores, o vencedor perfazendo uma média de 6 milhas por hora. O primeiro acidente de carro conhecido aconteceu em Nova Iorque em 1896, e o primeiro acidente fatal, também em Nova Iorque, em 1899.

Se eu estivesse contando uma história eu agora teria que continuar: "E então veio Henry Ford". O carro de Henry Ford para as pessoas... era uma noção fora do comum em 1907. Ele surgiu dos instintos populistas de Henry, que se ressentia com os ricos e com o monopólio por eles de uma vida abastada ...

Ainda a idéia não era exclusiva de Henry Ford. Outros fabricantes de carros tinham tentado fabricar um carro que pudesse ser produzido em grande escala a um baixo custo. A ambição de Henry era distinguida por gerar tecnologia e sólidas inovações de engenharia para fazer isto acontecer (Lacey, 1986: 86).

De fato, fabricantes de outros artigos, aparte dos fabricantes de carro, começaram naquele momento a farejar um mercado em massa, a existência de consumidores potenciais para artigos anteriormente acessíveis só para os ricos, dado que agora poderiam ser produzidos em larga escala e, conseqüentemente, mais baratos. A abertura de um mercado de produção em massa e assim de empresários produtores de bens para aquele mercado era um sintoma de uma característica transformação na estrutura das próprias sociedades industriais. A produção por meio de máquinas tinha, naquele momento, começado a gerar bastante riqueza nestas sociedades industriais permitindo aos empresários pagar seus empregados diretos e indiretamente. A rede inteira de negócios deles dependente perfazia uma renda suficientemente alta para permitir-lhes comprar o que previamente eram luxos inacessíveis. Os empresários agora eram capazes de fazer isso sem reduzir seus lucros e, na realidade, aumentando-os freqüentemente. Em outras palavras, o padrão de vida da grande massa popular estava subindo. Este mercado não foi produzido; foi vislumbrado e explorado por homens como Henry Ford. Assim começou a produção em massa de carros automotores, seu uso em massa nas rodovias dos países industrializados, e também assassinatos em massa. Uma pessoa, como mencionei, foi morta em um carro em 1899. Em 1974, os veículos automotores do mundo mataram 230.276 pessoas ao todo (Billian, 1976: 21).

\section{Algumas observações gerais na relação entre o Processo de Tecnização e o Processo}




\section{Civilizador}

Eu mostrei anteriormente que a palavra minúscula $\underline{e}$ no título "Tecnização e Civilização" pode ser facilmente mal compreendida. Hábitos atuais de pensamento conduzem muito facilmente à conclusão de que um destes dois processos provará ser o condutor, e o outro seguindo logo atrás; um agindo como causa e outro como efeito. Também se pode pensar que um processo como o econômico - até então não mencionado aqui - tem o papel principal e que ambos os processos em consideração tecnização e civilização - constituem-se em efeitos dependentes deste último importante processo. Mas eu acredito, como eu já disse antes, que a evidência não corresponde a este modelo simples de causaefeito. A interação das partes de diferentes processos é complexa e não tem começo. Eu não posso oferecer-lhes, com a melhor boa vontade do mundo, um processo novo e fundamental que estaria satisfazendo as necessidades ideológicas para causas, mas apenas o desenvolvimento da própria humanidade. A progressão na tecnização do transporte nos séculos dezenove e vinte é certamente impressionante, e não há dúvida de que o uso destes meios de transporte demandou alta disciplina entre os participantes, um autocontrole uniforme e moderado. Isto se aplica não somente ao condutor, ao motorista, ao piloto de aeronave e ao mecânico, mas também aos passageiros. Em muitos dos países adiantados os trens partem pontualmente no minuto do horário estabelecido, talvez até mesmo no segundo estabelecido. Eu já ressaltei em algum lugar (Elias, 1992) até que ponto a disciplina para o tempo social, torna-se segunda natureza para as pessoas nos países mais avançados. Isto não quer dizer, contudo, que tecnização é a causa e o autocontrole civilizador o efeito. Ou vice-versa.

A fim de retomarmos nosso caminho e prosseguirmos, a tecnização já demandou um grau relativamente alto de controle civilizador. $\mathrm{Na}$ busca por uma melhor compreensão do estágio das experiências preliminares no século dezenove e vinte - as quais no final das contas tornaram-se realidade na forma do automóvel e um pouco mais tarde na forma do aeroplano - havia uma observação que particularmente me impressionou. Em alguns aspectos os inventores mais conhecidos do século dezenove que compartilharam as experiências para desenvolverem o carro automotor e o aeroplano se assemelham um ao outro. Tomemos como exemplo Gehlen, o relojoeiro, que tinha feito experiências com dispositivos voadores já no começo do século dezenove, ou Otto Lilienthal da Pomerânia (e posteriormente Berlim) cujos planadores chegaram perto do projeto do avião de propulsão a motor, quando morreu em sua última tentativa de fazer voar um planador, e cujo trabalho preliminar conduziu eventualmente ao desenvolvimento de uma aeronave movida a motor pelos irmãos Wilbur e Orville Wright. Ou citemos Karl Benz ou Henry Ford. Não importa quem possamos usar como exemplo - o autocontrole e disciplina com que eles perseguiram sua meta durante muitos anos é impressionante. Eles nunca poderiam saber com certeza se esta meta poderia ou não ser 
alcançada. Todos eles começaram sem nenhum recurso financeiro, ou com muito pouco; e este pouco recurso financeiro que eles tiveram, de qualquer maneira, era provavelmente emprestado. Todos eles construíram sua primeira máquina - e quase sempre os motores - à mão em suas pequenas oficinas e, algumas vezes, em suas próprias cozinhas. Sem dúvida todos eles tinham dons incomuns, particularmente, mas não somente no campo da tecnologia. Eles também tiveram tenacidade em administrar seu trabalho experimental. Henry Ford e seus amigos, em seus esforços para construir um motor dirigível sobre um chassi de quatro rodas, esqueceram que a porta da oficina era muito pequena, para permitir a livre saída do invento para fora, rumo à estrada. Furiosamente, Ford arrancou os tijolos ao redor da entrada para pôr para fora o chassi para uma corrida experimental. Muitos destes inventores certamente eram homens jovens de visão. Eles sabiam que sua única chance de se tornarem bem sucedidos era inventando algo. Não podemos nos esquecer, porém, que foi a característica da sociedade da sua época que deu aos jovens uma chance relativamente boa de avanço desde que eles tivessem não somente o talento, mas também a disciplina necessária para a invenção tecnológica em questão.

O que eu estou dizendo é que o conceito de causa-efeito realmente não pode ser aplicado à relação tecnização-civilização. Na atualidade eles estão forçando o avanço e, no entanto, em alguns casos também retrocedendo.

Para a finalidade da investigação, e a fim de nos comunicarmos uns com os outros, estamos usando conceitos diferentes que nós podemos mentalmente controlar dissociando um do outro. Conceitos com os quais nós podemos trabalhar separadamente nos deixa esquecer tão facilmente que eles têm sempre a ver com pessoas co-existindo umas com as outras. É particularmente importante para os sociólogos, sempre que eles fazem uso de conceitos objetivadores, não perder de vista como estes realmente se referem a pessoas-em-seus-grupos. Há pessoas que fazem com que a tecnização aconteça em alguns aspectos de sua vida social, usam-na e, em retorno, estão eles próprios marcados por este processo. Também há pessoas-em-grupos que estão - por assim dizer - civilizando-se mais, ou decivilizando-se mais. O processo civilizador é um processo no qual seres humanos civilizam seres humanos. A linguagem que nos foi passada nos força, freqüentemente a pensar e falar de uma forma que claramente contradiz os fatos observáveis. Se um indivíduo deseja subjugá-los, talvez, inicialmente, vagueie demais para o outro lado e perca o contato com os membros de seu grupo, ou perca sua afeição. Talvez eu possa estar indo muito além se eu disser que "são as mesmas sociedades que se tornam mais tecnizadas e mais civilizadas". Mas pode ser de fato observado que um arranco na tecnização e um arranco na civilização, muito freqüentemente caminham de mãos dadas nas sociedades. Acontece também bastante freqüentemente que um arranco contrário também ocorre em uma fase recém-alcançada de tecnização, um arranco em direção à decivilização. 
Isso é exatamente o que pode ser observado quando o processo de tecnização de veículos de auto-estrada moveu-se do princípio de seu período experimental para o período de maturidade e para a produção em massa. Eu já ressaltei que todos estes processos são processos de aprendizagem. Quando uma inovação tecnológica como o carro automotor alcança maturidade, então as pessoas têm que começar a aprender com todos os tipos de experiências novas. Eles têm que aprender a remodelar suas cidades e a malha viária, a fim de que estas se tornem mais adequadas aos novos meios de transporte, pois estas foram todas originalmente projetadas, obviamente, para carruagens movidas a cavalo e para pedestres. As estradas, cobertas por pedregulho solto, por exemplo, tinham sido preparadas para coches puxados por cavalos e agora provavam ser muito perigosas para os veículos automotores. Em 1903, o Grande Prêmio Paris-Madrid de carros foi prematuramente adiado. Foram tantos os motoristas que bateram o carro após serem cegados pelas nuvens de pó que os organizadores pararam a corrida para salvar os motoristas sobreviventes. As autoridades tiveram que aprender. Os desenhistas tiveram que aprender. Os fabricantes das novas geringonças tiveram que aprender. E este grande processo de aprendizagem ligado à fase recentemente alcançada na tecnização de veículos de estrada era de preocupação particular aos beneficiários dos novos meios de transporte, os próprios motoristas. É de conhecimento comum que, no curso do século vinte, particularmente entre as nações industriais mais desenvolvidas - o assim chamado grupo Ocidental de estados - a posse do carro próprio de uma pessoa tornou-se um acessório normal, quase indispensável, para a vida. Assim o era, para a maioria das famílias e, freqüentemente, também para pessoas individualmente, jovens e velhos. Para muitas pessoas o carro se tornou uma parte deles, que aumentou a liberdade de movimento para todos de maneira até então desconhecida. Você dá ordem e o carro obedece, pelo menos enquanto você cuidou bem dele. Dá a seu "Senhor e Mestre” um poder que em tempos anteriores nem mesmo pessoas com um grande acompanhamento de criados à sua disposição tinham tido. Leva-os, quase sem esforço e com grande velocidade, por países; proporciona um prazer quase puro, mas às vezes também apresenta dificuldades. Ao todo, elevou a qualidade de vida a um custo tolerável.

Algo que nem sempre tem recebido a atenção que, todavia, merece foi o fato de que o arranco da tecnização trouxe para a grande massa de pessoas um novo impulso civilizador, correspondente ao novo arranco da tecnização. Foi este último que produziu o veículo automotor e, especialmente, o carro particular como um suplemento para a vida pessoal de um indivíduo. Obviamente, estradas para tráfego motorizado demandavam um certo grau de regulamento pelo Governo. Eu falei da Lei Inglesa de 1835 de Rodovia que estabelecia uma velocidade máxima de 4 milhas por hora. Desde então, a velocidade máxima estabelecida por lei tem em muitos casos sido deixada a critério de motoristas, individualmente. Este é um exemplo que mostra até que ponto, entre todos os regulamentos públicos, o tráfego motorizado depende de auto-regulamento pelo motorista. Este é o arranco civilizador o qual eu 
já mencionei anteriormente. Embora um certo grau de regulamentação e supervisão imposta por lei seja indispensável para a segurança de tráfego de automóveis, o nível de auto-regulação imposta pelo motorista a si próprio é e permanecerá decisivo para a segurança dos demais. Este é um dos exemplos mais concretos de como a tecnização e a civilização interagem. No que diz respeito a este aspecto nós ainda estamos no meio do processo de aprendizagem. As grandes vantagens e prazeres que provêm da propriedade e uso de automóveis privados, bem como dos comerciais, conduziu a algumas desvantagens quanto à sua aceitação. A taxa anual de acidentes é largamente aceita quase como algo inevitável. Mas uma vez confrontada com o fato, você não pode negar que o automóvel é acompanhado não apenas por arrancos civilizadores em direção a uma forma específica de autocontrole, mas, ao mesmo tempo, por um arranco decivilizador. Este fato é acompanhado por acidentes fatais com seres humanos e danos físicos freqüentes, muito deles, suficientemente severos para prejudicarem as pessoas pelo resto de suas vidas e infligir sofrimento.

Tem sido possível no curso dos anos, pelo menos nos países mais desenvolvidos, reduzir a taxa de acidentes consideravelmente. Isto era alcançado, principalmente, através de melhorias nos materiais usados no próprio carro automotor - mudanças materiais como vidros e especialmente o cinto de segurança. Até onde se sabe, a maioria dos países têm estado muito satisfeitos com regulamentos relativos ao consumo de álcool. Porém, o prazer pelo álcool implica somente em uma extrema redução na habilidade do autocontrole. As pessoas às vezes dizem: "Consciência e intelecto se dissolvem em álcool". Os limites no consumo de álcool impostos aos motoristas são certamente muito eficazes. Visto como uma figura absoluta, porém, o número de danos e, particularmente, de danos fatais relacionados aos veículos automotores, os acidentes são assustadoramente altos. Você pode estar muito certo de que o curso deve seguir, uma vez que nós temos aprendido a aumentar a segurança do carro até onde isso é possível, e lidar razoável com a diminuição do autocontrole individual pelo álcool em casos extremos de embriaguez. Assim a questão de outras faltas e falhas no autocontrole individual e, acima de tudo, o padrão social de autocontrole está se tornando o foco do problema dos acidentes agora. Este é, portanto, um problema civilizatório.

Diferenças em autocontrole podem ser observadas não somente entre pessoas da mesma comunidade nacional, mas também entre nações diferentes. A teoria dos processos civilizadores sugere que o autocontrole individual em sociedades menos desenvolvidas seja menos estável, menos uniforme e permanente que nos países altamente desenvolvidos. Correspondentemente, poderia se esperar que o número de mortos e feridos como resultado de acidentes de carro - como um fator resultante do número de carros em um país - seria mais alto em países menos desenvolvidos do que em países altamente desenvolvidos. Este realmente é o caso. Eu estou bem ciente das dificuldades estatísticas que se encontram em tais comparações. A definição de um acidente não é em todos lugares a mesma. Às 
vezes o número de mortos é levado a ser o número de todos aqueles que morrem dentro de trinta dias que sucedem um acidente. Mas se você levar em conta tais considerações, e então fazer não mais do que apresentar uma hipótese que pode bem valer a pena ser conferida, então você ainda pode permitirse ficar um pouco impressionado pelas diferenças enormes entre os coeficientes dos países mais desenvolvidos e dos menos desenvolvidos. A sugestão que tais diferenças possam ser vistas na efetividade de padrões sociais de autocontrole é, sob meu ponto de vista, merecedor de pesquisa mais profunda. Isto deve incluir consideração adequada sendo dada à eficácia do autocontrole e regulamentos legais impostos. A teoria de processos civilizadores oferece a possibilidade de uma explanação, em um contexto onde figuras estatísticas são normalmente registradas lado a lado sem nenhuma explicação. A tabela 1, reproduzida de Billian (1976:26) traz uma lista de países em ordem de ranking para o ano 1974. Esta tabela não tem a pretensão de ser confiável em todos os detalhes. Mas é um estímulo à reflexão. A regularidade com que o coeficiente nos países mais desenvolvidos é comparativamente baixo, e que nos países menos desenvolvidos, comparativamente alto, não se ajusta tão mal com a idéia de que diferenças entre sociedades em estabilidade e igualdade de autocontrole individual - e, neste sentido, no nível de civilização - tem um papel nas diferenças dos coeficientes.

Jan-Willem Gerritsen e eu podemos reivindicar um pouco mais de confiabilidade para as Tabelas 2 e 3, que nós mesmos elaboramos, baseadas em fontes que podem ser consideradas seguras. Durkheim pode talvez ser reconhecido talvez como a força atrás disto (3). Nós tentamos descobrir se um certo coeficiente (a relação do número de pessoas afetada por acidentes de carro ao número de carros registrados) mostra as mesmas diferenças ano a ano, quando comparações são tiradas entre países diferentes, não só durante um único ano, mas por mais de duas décadas. Nós calculamos um coeficiente baseado no número de feridos e, separadamente, pessoas mortas a cada 10.000 veículos (carros particulares e táxis). Como pode ser visto, as diferenças entre países diferentes realmente mostram uma constância muito considerável ao longo destes anos. Algumas pessoas serão inclinadas a interpretar tais constâncias em termos de características nacionais diversas. Deixe-me tentar pôr esta noção em termos mais concretos interpretando-os como variações nacionais no nível, e talvez também no padrão, de autocontrole pessoal.

Tabela 1 - Mortes na estrada:Estatísticas por Continentes 1974

\begin{tabular}{lrccc}
\hline Continentes & Habitantes & $\begin{array}{l}\text { Veículos } \\
\text { Registrados }\end{array}$ & $\begin{array}{c}\text { Número de } \\
\text { Mortes }\end{array}$ & Coeficiente \\
\hline Europa & $537,457,000$ & $98,122,777$ & 73,598 & 7.50 \\
América & $426,536,000$ & $151,354,858$ & 82,834 & 5.47 \\
Ásia & $2,365,451,000$ & $33,323,688$ & 47,978 & 14.39 \\
África & $281,668,000$ & $5,902,457$ & 21,404 & 36.26 \\
Oceânia & $17,915,000$ & $7,186,700$ & 4,462 & 6.20
\end{tabular}




$3,629,054,000 \quad 295,890,000 \quad 230,276 \quad 7.78$

Fontes: Estatísticas Oficiais publicadas por países específicos, e Estatísticas Mundiais de Estrada 1975 (Federação Internacional de Estradas).

Estatísticas de população para cada país são originárias das estatísticas publicadas pela União Postal Internacional, agrupadas por continentes.

Tabela 2 - Mortes na estrada como um Índice da Eficácia dos Padrões Sociais de Autocontrole /Número de pessoas mortas a cada 10,000 carros (carros privados e táxis) em diferentes países. [Resultados Provisórios]

\begin{tabular}{|c|c|c|c|c|c|c|c|}
\hline & 1955 & 1960 & 1965 & 1970 & 1975 & 1980 & 1982 \\
\hline Dinamarca & 27.9 & 18.0 & 13.6 & 10.0 & 6.0 & 4.7 & 4.6 \\
\hline França & 26.7 & 15.0 & 12.7 & 12.2 & 9.1 & 7.1 & 6.5 \\
\hline Alemanha & 75.0 & 33.2 & 17.6 & 13.7 & 8.3 & 5.6 & 4.8 \\
\hline Grã Bretanha & 15.6 & 12.9 & 8.5 & 6.4 & 4.8 & 4.0 & 3.8 \\
\hline Itália & 65.4 & 41.0 & 16.4 & 10.0 & 6.8 & 5.2 & 4.2 \\
\hline Países Baixos & 57.9 & 37.6 & 19.5 & 12.9 & 6.8 & 4.4 & 3.7 \\
\hline Noruega & 17.5 & 13.8 & 9.1 & 8.1 & 5.6 & 2.9 & 3.0 \\
\hline Suécia & 14.2 & 8.7 & 7.3 & 5.7 & 4.3 & 2.9 & 2.6 \\
\hline Grécia & $\mathrm{n} \cdot \mathrm{a}$. & $\mathrm{n} \cdot \mathrm{a}$. & 73.2 & 41.0 & 27.0 & 15.9 & 17.5 \\
\hline Portugal & 53.4 & 40.8 & 32.4 & 24.4 & 37.1 & 23.2 & 20.5 \\
\hline Espanha & 117.4 & 58.7 & 34.7 & 22.9 & 12.1 & 8.6 & 7.0 \\
\hline Turquia & 371.1 & 339.1 & 298.1 & 325.2 & 158.9 & 64.7 & 73.0 \\
\hline Estados Unidos & $\mathrm{n} \cdot \mathrm{a}$. & $\mathrm{n} \cdot \mathrm{a}$. & 6.5 & 5.9 & 4.2 & 4.2 & 3.6 \\
\hline Japão & $\mathrm{n} \cdot \mathrm{a}$. & $\mathrm{n} \cdot \mathrm{a}$. & 64.4 & 24.8 & 8.1 & 5.0 & 4.8 \\
\hline
\end{tabular}

Fontes: Relatório Estatístico em Acidentes de Estrada em 1983, ECMT, 1985,

Estatísticas de Acidentes de Estradas de Tráfego na Europa em 1980, ONU, 1981

Tabela 3 - Mortes na estrada como um Índice da Eficácia dos Padrões Sociais

de Autocontrole em alguns Países Asiáticos e Africanos/Número de pessoas mortas a cada 10.000 carros (carros particulares e táxis).

[Resultados provisórios]

Fonte: $\quad$ Estatística Mundial de Estradas1965-69, IRF, 1970

$\begin{array}{llll}1965 & 1966 & 1967 & 1968\end{array}$

Ásia

Índia

196.0

190.5

204.0

$x x$

$x x$ 


\begin{tabular}{|c|c|c|c|c|c|}
\hline Indonésia & 106.4 & 98.2 & $x x$ & 115.4 & 108.6 \\
\hline Iraque & 171.0 & 165.8 & 143.0 & 115.0 & 26.4 \\
\hline Japão & 64.4 & 55.2 & 39.9 & 30.8 & 26.4 \\
\hline \multicolumn{6}{|l|}{ África } \\
\hline Camarões & 52.9 & 42.1 & 43.6 & $x x$ & $x x$ \\
\hline Etiópia & 225.7 & 214.8 & 182.7 & 149.5 & $x x$ \\
\hline Costa do Marfim & 61.3 & 55.0 & 52.6 & 77.2 & $x x$ \\
\hline Quênia & 124.3 & 121.6 & 124.2 & 136.1 & 140.3 \\
\hline Uganda & 183.5 & 183.8 & 174.2 & $x x$ & $x x$ \\
\hline
\end{tabular}

Dados estatísticos sobre acidentes de automóveis são, freqüentemente, interpretados como dados sobre fatores impessoais. Isto me aparece ser inadequado. É difícil negar que o papel principal em acidentes de carros automotores é o das pessoas envolvidas, isso é, principalmente dos próprios motoristas. Controlar o carro (incluindo preservá-lo) é nada mais que uma extensão do autocontrole do motorista ou de sua auto-regulação. O padrão de auto-regulação do motorista no volante de seu carro, porém, é determinado em uma larga extensão pelo padrão social que a sociedade em cada país tem desenvolvido para a auto-regulação individual dos homens e mulheres que dirigem carros. Todos os tipos de regulamentos são incluídos neste padrão social de autocontrole individual pelos motoristas. Regulamentos legais, talvez relativos a limites de velocidade máxima, podem fazer parte disto, assim como políticas locais de sanções. Um componente adicional pode ser o código não registrado de comportamento de direção que, tacitamente, já pode ter se formado entre os motoristas em um país, e talvez como um padrão comum na Europa entre motoristas de um grupo inteiro de países. Por exemplo, pode acontecer que um limite de velocidade máxima de 60 milhas por hora em uma autoestrada seja obrigatório em um país, enquanto em prática uma velocidade de 70 a 80 milhas por hora é habitual e pode ser considerada como padrão. É decisivo para entender o que o coeficiente objetiva determinar que todos os regulamentos padrões, e todas as normas de tráfego de veículos, ao final estão relacionados ao autocontrole individual pelo motorista. Regras padrões na sociedade dele ou dela podem ter se tornado um hábito, a segunda natureza para o motorista. Um novato a estas regras pode precisar estar lembrando-as conscientemente, com uma ocasional cutucada à sua memória. De qualquer maneira que ele responda, o padrão social de regulamento é ineficaz se não é traduzido em autocontrole individual. Além disso, o autocontrole individual pelo motorista, o regulamento da própria conduta dele ou dela em relação a outras pessoas, permanece não direcionado e perigoso se não é orientado para padrões de regulamentos sociais os quais todos os motoristas compartilham. Um único motorista que falha em regular-se a si próprio dentro das condições do padrão comum representa um perigo a todos os demais. 
À primeira vista o conceito "padrão social de autocontrole" pode soar de uma alguma forma um pouco complicado. Pode precisar de um pouco de paciência para reconhecer sua produtividade. Corresponde exatamente aos postulados teóricos da teoria de processos civilizadores. Os exemplos de mudanças na conduta que são materializados em livros de boas maneiras em várias décadas ou séculos, simplesmente não estão relacionados a mudanças nos padrões autocontrole individual, mas sim às mudanças no padrão social de auto-regulação. O mesmo é verdadeiro, por exemplo, ao pronunciar-se. Um orador individual que quer ser entendido tem que seguir as regras em sua mente de um idioma padrão comum, e pode às vezes consultar talvez um livro de referência como o Dicionário de Inglês

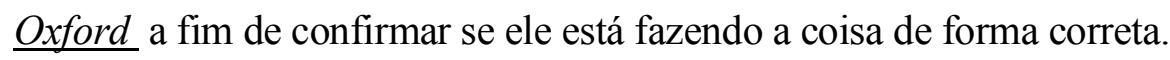

Teorias sobre "ação" e "comportamento" dão a impressão de que um ser humano é uma composição que consiste em uma multiplicidade de ações únicas do tamanho de um átomo. Ou seja, eles parecem imputar que aquelas ações únicas como um todo é tudo o que um ser humano pode perceber em outro. Talvez eles ainda retêm um pouco do "comportamentalismo casca de ovo". Falta uma ligação de uma pessoa como uma unidade de ações únicas integradas.

O conceito de autocontrole, como pode ser visto, pertence a uma imagem diferente de humanidade. É suficiente por agora simplesmente voltar a atenção a isto. Eu sugeri que os resultados nas Tabelas 2 e 3 deveriam ser interpretados como indicadores da eficácia do padrão social de autoregulação individual em diferentes países. As regularidades que podem ser observadas nesta e também na tabela precedente torna a interpretação da teoria dos processos civilizadores mais óbvia. Uma inspeção mais detalhada da Tabela 3 revela imediatamente a persistência com que o número de acidentes fatais de carro é e permanece mais elevada em países menos desenvolvidos do que em países mais desenvolvidos. O mesmo também é verdadeiro nos países menos desenvolvidos - Grécia, Portugal e Turquia - entre os países europeus na Tabela 2. A tentativa constante de periodicamente interpretar estatísticas sociais, quase determinada por natureza, como unidades impessoais de medida ocasionalmente obscurecem a visão até mesmo neste caso. Às vezes as pessoas tentam explicar o número maior de pessoas mortas nos países menos desenvolvidos apontando às estradas de qualidade inferior. Mas estradas não matam por si só. Certamente, estradas piores exigem maior precaução do motorista. $\mathrm{O}$ grande número de pessoas mortas nos países menos desenvolvidos não é então devido às condições das estradas, mas devido ao fato de que a auto-regulação do motorista não é, ou apenas o é a uma extensão insuficiente, adaptada às condições das estradas.

Os números para os países mais desenvolvidos (Tabela 2) provêm de certas indicações de como o desenvolvimento pode ser continuado através de melhorias na rede de estradas, bem como por meio da autodisciplina dos motoristas de acordo com as demandas da rede então melhorada. Do ponto de vista de uma teoria de processo o que é interessante é o entrelaçar de um processo não planejado e o 
planejamento humano. Os números ainda maiores para mortes nas estradas em 1950, mesmo nos países mais avançados, dão suporte à evidência de um processo não planejado. $\mathrm{O}$ nível de acidentes fatais de carro era decididamente não planejado. Foi então que lá começou o planejamento a fim de reduzir as chances de morte no tráfego motorizado. Esta idéia foi, até certo ponto, bem sucedida. Mas o aspecto não planejado do tráfego motorizado provou ser persistente. Em nenhum dos países era possível reduzir o número de acidentes fatais abaixo de uma certa quantia. Na opinião geral absoluta, o número de mortes no tráfego motorizado é ainda bastante considerável. É sem dúvida consideravelmente maior que o número de pessoas mortas por terroristas nestes países.

Os números para os países mais desenvolvidos dão certas indicações disto. O nível de mortes nas estradas nos anos cinqüenta, até mesmo nos países mais desenvolvidos, evidencia um processo que fabricantes e usuários de automóveis certamente não planejaram. Pode-se, inequivocamente, deduzir a partir destes números o efeito de um processo de aprendizagem. Todos os participantes - autoridades, fabricantes e, não menos, motoristas - metodicamente aprendem a aumentar a segurança ao dirigir, reduzindo o risco de morte do motorista. A eficácia do padrão de autodisciplina aumenta. Os coeficientes, pelo menos em todos os países europeus desenvolvidos, aumentam consideravelmente.

Uma pessoa só vê este processo com um pouco de clareza quando ela não estiver satisfeita com uma perspectiva de curto prazo, isto é, com coeficientes para um ou dois anos. Se você seguir a curva do processo por mais de 27 anos, então as comparações entre diferentes países dão um quadro informativo. Características estruturais diferindo nos países da amostra repentinamente emergem de forma mais clara quando se toma por base um longo período.

(a) Em toda parte, os coeficientes para os países menos desenvolvidos - Grécia, Portugal, Turquia e, em menor grau, a Espanha - na Tabela 2 são significativamente mais altos do que aqueles nos países mais desenvolvidos. E, embora eles baixem notavelmente no curso dos 27 anos em todos os quatro países europeus menos desenvolvidos que são registrados aqui, eles permanecem ao mesmo tempo, notavelmente mais altos que os coeficientes igualmente cadentes nos países mais desenvolvidos.

(b) Algumas regularidades também são salientes nos países mais desenvolvidos (Tabela 2). As estatísticas mostram mais clara e confiavelmente, diferenças significantes nas colunas de dados para os países diferentes. Há uma semelhança notável na coluna que representa os três países que sofreram derrota na Segunda Guerra Mundial: Alemanha, Itália e Japão. No caso da Alemanha e Itália os coeficientes para 1955 são 55 e 65, e eles reduzem gradualmente para 5.6 na República Federal, e para 5.2 na Itália. O coeficiente do Japão em 1965 é 64.4 e então rapidamente cai para 4.8 em 1982. Uma pessoa esperaria que a ascensão do Japão à classe dos países altamente desenvolvidos traria com isto aquele modelo padrão de auto-regulação - ou seja, principalmente maior estabilidade e igualdade de 
auto-regulação - que é indispensável a uma sociedade altamente tecnológica em competição com outras sociedades semelhantes. Na Tabela 3, a característica surpreendente dos dados na coluna do Japão torna-se particularmente evidente em comparação com os dados nos três outros países asiáticos. Estes são todos países em "desenvolvimento" - ou seja, em linguagem menos apologética, países menos desenvolvidos e correspondentemente mais pobres. O dados destes países se alinham com o que a teoria dos processos civilizadores prediz, que a igualdade, estabilidade e toda a harmonia do autocontrole individual são mais baixos em tais sociedades. Um levantamento de amostras comparativas do grupo de países africanos mostra um quadro similar. Uma amostragem experimental mais detalhada que fizemos mostrou diferenças significantes entre os países anglofônicos e francofônicos da África. O coeficiente é notavelmente muito mais baixo na maioria dos países francofônicos do que nos países anglofônicos, entretanto significativamente mais alto que os coeficientes nos países europeus mais desenvolvidos.

Seria talvez um pouco arriscado falar de um coeficiente de civilização. O que eu estou apresentando aqui certamente são diferenças na disposição social dos membros das sociedades altamente desenvolvidas e outros de sociedades menos desenvolvidas. Por favor, observe: diferenças na disposição social, não diferenças biológicas. O Japão é um bom exemplo do fato de que tais diferenças no autocontrole podem mudar no curso de desenvolvimento social.

Quando as pessoas nos países menos desenvolvidos dirigem de um tal modo que eles causam morte e danos, então é falha das pessoas e, em particular, de sua própria maneira imperfeita de dirigir, e não das estradas como tais, nem dos veículos que estão sendo guiados por elas. As pessoas nos países menos desenvolvidos, aparentemente, só se movem juntos sem se importar com as condições motrizes ruins. E isto é exatamente o que eu quero dizer quando eu falo de um nível social mais baixo de padrões ao conduzir-se $\underline{a ~ s i}$ próprio. De fato este é exatamente o ponto para o qual eu gostaria de chamar a atenção. A pobreza brutaliza as pessoas. Isto não é para ser interpretado com uma declaração concernente a pessoas como indivíduos, mas sociedades. Quando um indivíduo alcança um nível mais alto de civilização, o código do comportamento e sentimento que encoraja um autocontrole mais uniforme e estável, não é porque as pessoas interessadas são, por assim dizer, mais civilizadas por natureza. O padrão mais alto na estabilidade e constância de seu autocontrole não é inato neles. Este padrão é uma parte integrante e, ao mesmo tempo, uma condição e conseqüência de um estágio mais avançado de desenvolvimento, e assim também, da maior riqueza da sociedade deles. As largas autoestradas, bem construídas, bem sinalizadas e muitas bem planejadas custam muito dinheiro. Elas são projetadas para motoristas prudentes. Relativamente, piores redes de auto-estradas em muitos países menos desenvolvidos e a maior falta de consideração mostrada pelos motoristas, não estão em uma relação de causa e efeito. Ambos são sintomas de pessoas vivendo juntos socialmente em um estágio 
inicial de desenvolvimento social.

Eu não tenho medo de falar de sociedades em estágios diferentes de desenvolvimento e certamente não de sociedades mais pobres e mais ricas. Mas algumas pessoas têm medo de reconhecer o que é bem conhecido ao observador atento, que estágios diferentes de desenvolvimento caminham de mãos dadas com estruturas de personalidade diferentes.

Uma breve referência à transformação incrivelmente rápida dos japoneses talvez possa ajudar a ilustrar o problema que eu tenho em mente. Laurens van der Post, o escritor sul-africano residente na Inglaterra, em uma entrevista de rádio, chamou o caráter nacional japonês de semimedieval. Ele achava que o Japão tinha sido uma nação orgulhosa, elegante, feudal, de guerreiros que olhavam para si mesmos, em suas ilhas não conquistadas, como o centro do mundo. Por terem sido forçados a deixar seu isolamento e por terem se permitido a entrar em uma família maior de pessoas, continuou Van der Post, esta nação estava agora se vingando através de sua rápida ascensão econômica e superioridade tecnológica. Uma observação concernente à relativa à Segunda Guerra Mundial deveria ser o bastante para realçar o método tradicional da auto-regulação japonesa:

Tropas civilizadas mostraram uma pronunciada tendência por preferirem render-se, quando eles eram cercados, a continuar uma resistência sem esperanças; o "japonês menos civilizado" apresentou um problema difícil por não estar preparado a se render, não importavam as circunstâncias. (Cambridge História Moderna, 1960, Vol. 12, pág. 276)

O código de guerreiro tradicional dos japoneses fez com que ser capturado vivo parecesse humilhação imperdoável. Isto criou, então, uma forma extrema de autocontrole, um fanatismo que não permitiu, assim, nenhum ajuste a circunstâncias variáveis. Resultou em um desprezo ilimitado pelas Forças Aliadas que tinham se deixado ser capturadas quando a resistência não oferecia esperança. A parte correlativa ao grau extremamente alto de autocontrole mostrado pelos japoneses em certos aspectos era, por exemplo, a capacidade extrema para realizar prazeres sádicos nos seus prisioneiros. É possível que somente o Imperador japonês estivesse em posição de persuadir a uma quebra neste código fazendo com que os japoneses renunciassem depois que as primeiras bombas atômicas americanas tinham sido lançadas. A partir de então, tem havido uma mudança gradual na estrutura da personalidade dos japoneses. Está entre as peculiaridades de tais mudanças civilizadoras na estrutura da personalidade, e mudanças especialmente nos padrões sociais de autocontrole, que eles sigam outras mudanças sociais, talvez as econômicas e tecnológicas, normalmente apenas depois de um lapso de tempo. $\mathrm{Na}$ Tabela 2 a linha de números representando os japoneses - a qual realmente difere muito consideravelmente de todos os outros países mais desenvolvidos - mostra o modelo japonês de autocontrole em uma curva superior. O modelo de padrão de autocontrole demandado pelo tráfego de veículos automotor é, naturalmente, bastante diferente do código de um cortesão ou um guerreiro. Como pode ser visto, em 1970 o coeficiente japonês indicou um autocontrole mais baixo que o alemão, tornando-se mais alto em 1974 e tem sido aproximadamente o mesmo desde 1981. É necessário ainda 
ser investigado se esta mudança no padrão de autocontrole em estados modernos, que está baseada em um grau elevado de autocontrole autônomo pelo indivíduo, surge mais em constrangimentos reforçados pelo estado e pela polícia, ou mais do autoconstrangimento. (Em estados modernos baseados em um alto grau de auto-regulação automática pelo indivíduo, estes elementos são distingüíveis, mas não dissociáveis.) Para o momento, porém, isto não é importante para os nossos propósitos.

O espaço de tempo, por outro lado, entre as linhas do desenvolvimento tecnológico e outros da sociedade, e, por outro lado também, as mudanças correspondentes na estrutura da personalidade, são problemas centrais na relação entre os processos de tecnização e civilização. Talvez eu posso ilustrar este problema através de alguns exemplos.

Pense uma vez mais na revolução do transporte e suas conseqüências nos séculos dezenove e vinte. As estradas de ferro e os veículos automotores aceleraram o movimento de mercadorias e pessoas, e deu-lhes uma liberdade de movimento até então desconhecida. O aeroplano intensificou este processo de redução de distâncias entre as pessoas sobre todo o globo terrestre, a uma extensão tal que agora é difícil imaginar - a menos que você tenha uma memória vívida de sua própria existência - o tempo do não-conhecimento, antes das aeronaves se tornaram meios cotidianos de transporte para mercadorias e pessoas, na paz e na guerra. Havia um período inicial longo de experimentação no caso do avião, da mesma forma que tinha ocorrido no caso do veículo automotor. Europeus de muitas nacionalidades, bem como americanos, tiveram parte nisto. Eles compartilharam o conhecimento - o que não era absolutamente óbvio - que uma máquina voadora utilizável não poderia ser construída por um pensamento desejoso e sonhador, mas apenas pela combinação de paciência para a experimentação e modelos teóricos testáveis e cálculos. Muitos dos envolvidos publicaram os resultados de suas experiências e de seus desígnios propostos nos novos periódicos dedicados a aviação. Entre aqueles que contribuíram com experiências neste período inicial de desenvolvimento estavam, apenas para nomear alguns, Artingstore e Cayley na Inglaterra, Ader e Pénaud na França, Fornalini na Itália (com um avião de hélice propulsora), e Otto e Gustav Lilienthal na Alemanha. Muitos deles estudaram e discutiram o vôo dos pássaros. Os experimentos com planadores não motorizados baseados no movimento de planagem dos pássaros em retrospecto como um estágio preliminar quase indispensável à inovação que conduziu ao aeroplano motorizado. A dificuldade era que as máquinas a vapor possuíam poder insuficiente em relação ao seu peso. O desenvolvimento do motor alimentado por petróleo junto com as experiências iniciais dos muitos entusiastas, o trabalho detalhado desses que nunca alcançaram fama - em resumo, o processo social - ajudou os irmãos Wright em sua inovação final no começo do século vinte, quando eles obtiveram sucesso construindo uma máquina voadora que era capaz de transportar nas alturas, simultaneamente, uma máquina e uma pessoa, e poderiam ser 
ambos conduzidos seguramente no ar e ao pousar.

Você talvez possa obter um quadro mais claro do que está acontecendo hoje no trabalho experimental com espaçonaves se você tiver em mente o longo período de experimentação inicial com carros e aviões movidos a motor. E em troca os posteriores parecem mais impressionantes quando você tiver em mente a incerteza presente, a falta de conhecimento com respeito à forma futura e conseqüências da viagem espacial. Os pioneiros do carro automotor e do aeroplano também correram riscos. Otto Lilienthal foi fatalmente ferido em um acidente com planador, pouco antes do teste que ele tinha planejado fazer, usando sua própria máquina.

Uma diferença é imediatamente aparente, entretanto. Foram pessoas, individualmente, que fizeram experimentações no século dezenove. A maioria deles, inclusive Henry Ford, construiu os protótipos à mão em suas pequenas oficinas. Ao mesmo tempo, eles construíam as suas próprias máquinas e peças sobressalentes. Eu mal posso dar um exemplo de desenvolvimento direcional mais inequívoco do que esta diferença na estrutura de invenção tecnológica à vanguarda da revolução no transporte. As demandas tecnológicas e os custos à vanguarda da tecnologia de transporte hoje em dia são tão grandes que só as nações mais ricas podem se permitir competir um com o outro para tais invenções. Estas nações gastam enormes somas para este propósito. Elas excedem umas às outras. As experiências conduzidas por um lado leva o outro lado a considerar aquele como uma ameaça à sua segurança - ou seja, eles se sentem ameaçados no campo militar. Não foi sempre assim. Os irmãos Wright ofereceram à venda sua invenção ao governo americano, mas a oferta foi recusada. $\mathrm{O}$ governo da França, da Inglaterra e Alemanha mostrou maior interesse pela nova máquina voadora. Mas Wilbur e Orville Wright patrocinaram seus vôos experimentais dos anos 1890 até 1907 com os lucros da modesta loja de venda e conserto de bicicletas. Seu primeiro vôo bem sucedido, em dezembro de 1903, é lembrado através das gerações posteriores. Seus contemporâneos fizeram pouco caso. Foi somente quando eles organizaram exibições aéreas, particularmente na Europa, e até mesmo levaram passageiros, que alguns outros setores públicos, particularmente os Ministérios de Guerra das grandes forças rivais da Europa se deram conta que a invenção de um aeroplano realmente utilizável de fato tinha obtido êxito.

Uma invenção desta magnitude, porém, com o potencial para uma revolução de propagação contínua nos meios humanos de transporte, necessitou de uma nova estrutura organizacional para que a invenção puramente técnica operasse dentro dela. No princípio havia, obviamente, uma falta absoluta de instituições sociais, como aquelas para o fabrico de aeroplanos e para a criação e supervisão do tráfego aéreo. A rivalidade que se poderia esperar surgir entre nações pela superioridade na fabricação dos melhores aeroplanos revelou-se no princípio em patentes disputas, por exemplo, na França. O desenvolvimento adicional do aeroplano, tecnologica e organizacionalmente, recebeu seu ímpeto 
inicial principal - como têm acontecido repetidas vezes, em grande parte para a angústia da humanidade - da rivalidade militar entre as nações. O primeiro vôo regular de passageiros, pelo menos até onde eu sei, foi inaugurado logo após a Primeira Guerra Mundial na rota Londres-Paris. Este foi seguido por um serviço aéreo em 1920 entre Londres e Amsterdã.

Durante a guerra, porém, batalhas envolvendo aeronaves deram origem a um novo desenvolvimento. Agora, ao final do século vinte, isso tudo é muito familiar. No período presente de paz relativa na qual nós vivemos, sem saber totalmente se é ou não um período que precede outra guerra, nós o chamamos de uma corrida armamentista. Mas isto é muito vago. Pode talvez ser visto um pouco mais claramente se você voltar os olhos para a guerra de 1914-18 e a corrida infinita naquela ocasião por uma aeronave melhor. Em si mesmo, a indagação do porquê um armamento melhorado, se para o ataque ou defesa, a luta entre forças de exércitos adversários não era novidade. Por um longo período, oponentes militares do passado tinham buscado ganhar a vantagem em suas batalhas usando espadas melhores, galeras de guerra melhores, canhões e armas melhores. A tecnização da guerra entrava em uma nova fase, porém, com o uso de aeronave com propósitos militares. Até mesmo as aeronaves primitivas da Primeira Guerra Mundial provavelmente foram - talvez com a exceção do navio a vapor - as máquinas mais complexas nas mãos dos militares. Com elas a cientificação ${ }^{1}$ da guerra começou a agravar-se. Sob esta pressão engenheiros e cientistas puseram-se ao trabalho para triunfar sobre o inimigo através da melhoria contínua das máquinas. Correspondentemente, as grandes forças da Europa em conflito envolveram-se em uma corrida armamentista, cada qual forçando aos outros melhorias e inovações nos aviões de guerra em um ritmo até então desconhecido.

Nós agora estamos acostumados, e raramente surpresos, com o ritmo do desenvolvimento tecnológico. Na ocasião da Primeira Guerra Mundial isto era ainda algo totalmente surpreendente. $\mathrm{Na}$ Inglaterra, o Ministro responsável por obter munições era provavelmente o primeiro a interessar-se com provisões para aeronaves. Em 1917, o Ministro de Munições deu uma entrevista na qual ele disse:

\footnotetext{
O desenvolvimento tecnológico do aeroplano apresenta seus próprios problemas. Novos tipos estão sendo desenvolvidos continuamente. Nunca tem sido possível afirmar: "Este é o último modelo de aeronave e os projetos industriais podem ser agora arquivados". Dificilmente tem sido uma máquina testada e aprovada, bem como dificilmente alguém tem conseguido corrigir suas falhas de forma que ela trabalhe tão confiavelmente como uma máquina alemã mais rápida. Os pilotos ficam deprimidos. $\mathrm{E}$, um pouco depois, um novo modelo britânico de aeroplano aparece, e então o modelo alemão é deixado de lado.
}

E um comentário sobre isto afirma: "O resultado final então não foi alcançado, e provavelmente nunca poderá ser alcançado na construção de aeronaves. Um tipo de avião que é

\footnotetext{
1 N.T. Tradução segundo o sentido que o autor dá à palavra, sendo este provavelmente um neologismo.
} 
considerado o melhor hoje, pode ser ultrapassado amanhã. Neste sentido, alguém nunca pode cessar sua busca por melhorias". O primeiro Ministro francês para tecnologia de manufatura de aeronave militar ressaltou que não se pode produzir aeronaves em massa como se produzem munições de artilharia. Você mal se adaptou a uma melhoria, quando outra inovação essencial é requerida. Até mesmo a pausa mais breve deixaria o inimigo em posição de vantagem.

Um inglês na Primeira Guerra Mundial expressou a opinião que realmente já não eram uma nação ilhada, devido à importância militar crescente do aeroplano. Essa afirmação foi feita pela primeira vez desde Henry VIII, quando a Inglaterra demonstrava seu poder naval crescente. Mas esta percepção realística significa relativamente pouco em casos deste tipo. A maioria dos ingleses ainda sente o mesmo no fundo do coração, ser uma nação ilhada. É esta dificuldade que as pessoas têm em ajustar-se às mudanças no seu mundo que está conectado à velocidade sempre crescente de mudanças na tecnologia e organização que me incitam a algumas observações finais.

Conclusão

Eu tentei salientar que o desenvolvimento de novos meios de transporte, principalmente o automóvel e o avião, não são projetos vagos, mas devem ser entendidos como processos não planejados derivados do desenvolvimento das sociedades européia e americana nos séculos dezenove e vinte. Porém, a transformação revolucionária do transporte que começou com o trem desta forma, em troca reage sobre a sociedade que a tinha produzido. Por exemplo, o avião sem ser - como é dito com freqüência - a causa de uma transformação social importante altamente sociológica que começou no século dezenove, mas tornou-se efetiva, principalmente, no século vinte tem, sem dúvida, uma parcela muito considerável nisto. Eu me refiro à integração rapidamente crescente da humanidade, à interdependência crescente de todos ao até então independentes subgrupos da humanidade. $\mathrm{O}$ tráfego aéreo crescente uniu pessoas, independente de todos os obstáculos globais, apesar de todos os oceanos e montanhas, de todos os desertos e geleiras. Colocou todos os grupos de pessoas rapidamente em contato uns com os outros, e alcançou isto com grau relativamente alto de segurança. No século dezoito a palavra "humanidade" era associada a um sonho bonito, mas irrealizável (Elias, 1939/1994: 3-28). Hoje a humanidade se tornou uma unidade em maior grau que antes e, se eu posso assim dizer, uma realidade social. Não somente o avião, mas também o telefone, o rádio e, em particular, a televisão, têm proporcionado às pessoas uma proximidade maior através do planeta. É possível encontrar filmes americanos em domicílios africanos. Guerrilhas sul americanas aparecem "ao vivo" nas telas das TVs européias. Índios nas suas casas assistem as batalhas na Irlanda do Norte. Porém, é duvidoso se Sikhs² e Hindus, Tamils e Singaleses, Bascos e Espanhóis, Católicos e Protestantes

\footnotetext{
${ }^{2}$ N.T. Membro de uma religião - Sikhism - que se originou do Hinduísmo no século 16 e é baseada na crença de um único Deus.
} 
Irlandeses se identificam quando a televisão os mostra, retratados em seus próprios contextos de equivalência. $\mathrm{O}$ avanço na tecnização tem colocado as pessoas, sobre o globo terrestre, cada vez mais próximas umas das outras. Mas o desenvolvimento do habitus humano não está acompanhando o ritmo do desenvolvimento da tecnização e suas conseqüências. A tecnização encoraja a humanidade a aproximar-se e a unificar-se. Quanto mais isto acontece, mais as diferenças nos grupos humanos se tornam aparentes à consciência humana. A integração crescente da humanidade, a dependência rapidamente crescente de todos os subgrupos da humanidade um com o outro são expressas não apenas em uma série inteira de instituições globais tais como o Banco Mundial ou as Nações Unidas, mas também em tensões específicas e conflitos que surgem da integração. Na África, tribos fundem-se aos estados sob a pressão do poderoso arranco de integração na qual nós nos achamos. Aqui ele pode ser muito claramente reconhecido como o habitus tradicional das pessoas. Um habitus inicialmente baseado na sua identidade com a tribo entra em conflito com a necessidade de juntar-se em unidades maiores, em estados. Um processo análogo em um nível diferente pode ser observado na Europa. A pressão pela unificação dentro de uma estrutura européia maior é inconfundível. Mas o habitus das pessoas, o modelo dominante de seu autocontrole, é focalizado na identificação com estados soberanos.

Nos dias primitivos da existência da espécie humana - que realmente não são fáceis de visualizar - havia possivelmente não mais que um punhado de seres humanos nesta terra semelhantes ao nosso gênero. O tempo presente é talvez o único tempo em que os seres humanos formaram coletivamente uma unidade social real, não simplesmente como um ideal bonito, mas como uma realidade social. Mesmo agora o fato não é completamente entendido que o processo de integração humana crescentemente mais ativo está caminhando em direção à interdependência regional da humanidade e sua pacificação interna, bem como eliminando as diferenças de riqueza. Isto não é fácil de entender, porque o processo global que se move naquela direção leva com ele, como sempre em tais casos, forças poderosas de um processo oposto. E estas últimas, devido à miséria humana que as acompanha, estão mais claramente nas mentes das pessoas que as primeiras.

Além disso, as pessoas ainda estão bastante desacostumadas a esta tendência de "vamos nos aproximar". É uma das características imutáveis no ritmo acelerado das mudanças que toda a perspectiva das pessoas na vida continua sendo psicologicamente atada à realidade social de ontem, embora a realidade de hoje e de amanhã já difere grandemente da de ontem.

Hoje, o avião uniu Berlim, Washington e Moscou em espaço e tempo mais que as capitais da Europa continental no século dezenove. Mas a atitude emocional dos europeus uns para com os outros e das pessoas da Rússia e América continua aderindo ao modelo do passado em muitos aspectos. E o mesmo certamente é verdadeiro com relação à atitude dos próprios americanos e russos. 
Emocionalmente, eles estão tão longe uns dos outros como eles estavam no século dezenove.

Eu expliquei desde os anos trinta, aproximadamente 50 anos atrás - auxiliado por investigações teórico-empíricas - que uma teoria de interdependência é indispensável para sociólogos, e que sua função central na investigação de sociedades não pode ser conhecida pelas teorias de ação e interação prevalecentes naquele momento. $\mathrm{O}$ avanço triunfante do avião, como um meio para o tráfego global na paz e na guerra, tem contribuído decisivamente para a crescente interdependência de todos os estados no globo terrestre e, ao mesmo tempo, é também o seu produto. Tem uma influência civilizadora enorme, ao trazer as pessoas de todas as regiões para mais perto umas das outras. Isto acontece não somente porque ele ajuda pessoas de todas as raças a se acostumarem umas com as outras, não importando o quão diferente sejam seus modelos de autocontrole. As crescentes interdependências, porém, são acompanhadas muito regularmente por tensões específicas e conflitos. Nenhum grupo de pessoas fica satisfeito quando se dá conta de que agora é mais dependente dos outros do que antes. Eu tenho chamado tais tensões de "tensões de integração e de desintegração". Elas dominam o cenário social dos estados no recente século vinte. Aqui, também, o impulso civilizador na direção de uma humanidade mais unida está aliado a um impulso decivilizador contrário. As tensões e conflitos que a interdependência crescente traz consigo são - até então - somente de importância secundária. Esperamos que isso nunca mude.

Um exemplo breve talvez possa ajudar esclarecer a contribuição feita pelo desenvolvimento tecnológico neste empurrão em direção à interdependência com seu potencial civilizador e decivilizador. Lembre-se que no século dezenove um Czar russo relativamente pobre vendeu o Alasca aos Estados Unidos da América. A Rússia e a América estavam então tão longe um do outro que ninguém, obviamente nem mesmo o Czar e seus conselheiros, pensou que os dois países pudessem possivelmente tornar-se rivais militares e que poderiam impor uma ameaça mútua à sua própria segurança (4). O aeroplano contribuiu até certo ponto por isto ter mudado. Mas não vamos cometer o erro de colocarmos o processo de tecnização, por assim dizer, no seu exato princípio. Como muitos outros processos que contribuem para o desenvolvimento da humanidade, a tecnização tem um impulso imanente que continuamente recebe novos ímpetos da rivalidade entre os indivíduos e entre grupos de pessoas. Mas outros processos colaboradores também recebem continuamente novos ímpetos - exatamente como a tecnização em si. Eles recebem isto da predominante composição global da humanidade, do dinamismo do desenvolvimento da humanidade e das várias unidades sobreviventes - das tribos e estados que eles formam com o passar do tempo. O ímpeto imanente de partes de processos como a cientificação, a tecnização, o desenvolvimento econômico, ou a formação de estados tem sempre somente uma autonomia limitada dentro da estrutura do desenvolvimento total da humanidade. O processo global pode ser guiado em uma ou outra direção, ou pode até mesmo ser 
interrompido ou invertido pelas rivalidades e pela luta por poder entre grupos de pessoas e seus representantes individuais.

Eu não gostaria de dar a impressão de que eu quero atribuir ao desenvolvimento técnico - ou em um senso ainda mais limitado, à revolução do transporte - o papel de iniciador, de "primeira causa" neste movimento de integração. Para mim, a explicação repousa na dinâmica intrínseca da própria humanidade da qual eu já formulei um exemplo no modelo do processo de monopolização no segundo volume de meu livro O Processo Civilizador (1994; orig. 1939). Aqui eu dei outra representação esquemática desta dinâmica. É a dinâmica intrínseca da humanidade da qual o derradeiro esforço bem sucedido para meios de transporte cada vez mais rápidos, automóveis, aeronaves e astronaves derivaram sua força. Porém, pode ser igualmente dito que ao mesmo tempo o nível de integração da humanidade, que oscila para lá e para cá, mas está sendo impelido agora por sua própria dinâmica, não fosse por este tipo de impulso tecnizador - teria sido inacessível diante do risco sempre presente de desintegração. Costumava-se às vezes imaginar que o desenvolvimento tecnológico, o desenvolvimento cultural, e talvez até mesmo o desenvolvimento econômico e social foi, por assim dizer, eventos autogovernantes, cada um projetando seu próprio curso independentemente. Você poderia então questionar se o movimento ao longo de cada um destes canais teve seu próprio impulso, ou se um destes movimentos subsidiários estava fornecendo ao movedor principal de todos os outros. Mas de acordo com os fatos desta natureza - de qualquer modo se mudanças naturais enormes como a vinda e o transcurso da Era do Gelo são postas de lado - você procuraria em vão explicações para mudanças na humanidade que se encontram fora da própria humanidade. Você então chegaria aos limites das explicações casuais. É necessário então um período de ajuste para reconhecer que as explicações para mudanças na estrutura da humanidade devem ser buscadas na estrutura da própria humanidade, em sua dinâmica intrínseca, e não fora dela ou em outro "subsistema".

Desenvolvimentos tecnológicos, como o avião ou a televisão, aumentaram a pressão rumo à crescente interdependência e, correspondentemente, em direção a uma maior integração institucional. Eles apresentaram assim às pessoas uma tarefa civilizadora - e isso é difícil. Não pode ser dito com antecedência se eles podem controlar esta situação ou não. Mas a tarefa civilizadora está clara em si mesma. O autocontrole das pessoas é (de acordo com suas origens, e então compreensivelmente) atrelado à identificação com pequenos sub-grupos da humanidade, tribos ou estados. Comparado com a importância emocional da própria tribo do indivíduo, seu próprio povo, sua própria nação, o conceito de humanidade é uma palavra vazia. É de fato uma grande parte, mas não somente, por causa dos desenvolvimentos tecnológicos que as pessoas se encontram agora na posição de estarem preparadas, no final das contas, para viver em paz umas com as outras ou perecerem em guerras futuras umas com as outras. Este é um processo de aprendizagem. Não se pode saber como terminará. É, como tantos 
outros processos entre os quais nós vivemos, um processo social inacabado.

Eu tentei dar, através de uma discussão da relação entre dois processos parciais, o processo de tecnização e o processo civilizador, o exemplo de uma forma de fazer pesquisa sociológica que se esforça consistentemente para evitar reduzir os processos sociais a algo estático. Isto é alcançado apresentando $\underline{\text { como }}$ processos sociais àqueles processos que podem ser na verdade ser observados como tais na investigação e não os reduzindo a estados ou leis, a algo eterno, no modelo talvez de físicas clássicas (5). O modelo da revolução do transporte dos séculos dezenove e vinte, da máquina a vapor ao carro automotor, e do aeroplano à astronave, é um exemplo ideal de um processo não planejado e - como pode ser visto - também de um processo inacabado. Eu tenho me perguntado freqüentemente por que é tão difícil para um processo sociológico trazer progressos, por que é tão difícil para muitas pessoas perceberem mudanças nas sociedades humanas - e particularmente em mudanças de longa duração - como processos estruturados, e investigá-los como tal. É, aparentemente, mais fácil e provavelmente mais satisfatório para a maioria das pessoas, e muito provavelmente também para a maioria dos sociólogos, imaginar o mundo como basicamente imutável, fundamentalmente em constância. Este também é o quadro cultivado por cientistas de Newton a Einstein e além. Mas a influência de se pensar em termos de processos começou a afetar até mesmo as físicas contemporâneas, apesar de no princípio marginalmente, somente na periferia. O conceito de um universo constantemente variável, e pensando assim no universo como um processo, de alguma forma contradiz a concepção de natureza imutável. Parece-me que há boas razões pelas quais o conceito de um mundo constantemente variável não é achado emocionalmente desejável, nem particularmente satisfatório. Se você imagina o mundo, ou uma sociedade, como um processo, então você é lembrado de um fato que gostaria de evitar recordar. Você é lembrado que, após sua própria morte, a sociedade futura das pessoas muito provavelmente será bem diferente em muitos aspectos do mundo presente no qual hoje vivemos. O mundo presente, o mundo do século vinte, parecerá às pessoas do próximo século ter sido bastante antiquado e substituído em muitas formas - provavelmente na mesma extensão como nós vemos o mundo das diligências, ou o mundo no qual foram feitas experiências com carros automotores a 4 milhas por hora e no qual foram feitas tentativas de voar com asas feitas de 10,000 penas de ganso, como fez Clemente Adie. O tipo de pesquisa prevalecente entre a maioria dos sociólogos concentra-se na procura por algo que parece ser um estado constante e talvez até mesmo eterno - algo que, se não tiver existência externa, então está pelo menos dotado de validez eterna no senso filosófico. Há aparentemente apenas uma alternativa para este eternalismo, que é o historicismo do pesquisador histórico. Face a face com um mundo que é preso a uma mudança infinita, o historiador geralmente representa isto como mudança contínua sem qualquer ordem, sem qualquer direção ou estrutura. Se você levar o historicismo dos historiadores a sério, então declara basicamente que o que 
quer que esteja acontecendo no século vinte poderia igualmente ter acontecido há duzentos ou até mesmo dois mil anos atrás. E reciprocamente, os eventos do Mundo Antigo poderiam igualmente acontecer hoje ou amanhã. As grandes falhas dos historiadores são a falta de uma concepção não dogmática clara do desenvolvimento das sociedades humanas. Originalmente, o conceito de desenvolvimento foi retirado dos livros de história porque era uma teoria específica de desenvolvimento que se tornou o credo do Marxismo. Eles simplesmente descartaram uma idéia valiosa, como se estivessem se livrando de algo indesejável. Porque a teoria de desenvolvimento de Marx tinha sido amarrada a uma profecia do estado futuro da humanidade, o conceito de desenvolvimento de longa duração foi completamente eliminado dos livros de história. O desenvolvimento que levou da diligência à estrada de ferro e ao carro automotor, e do aeroplano a fazer experiências com astronaves é um exemplo pequeno de um processo social em uma direção definida, mas certamente sem um objetivo e não envolvendo nenhuma profecia sobre onde tudo isso poderia conduzir.

O conceito de desenvolvimento não é essencial somente quando você estiver se esforçando para investigar mudanças tecnológicas. Imagine que não há aviões e você se também se encontra politicamente em um mundo diferente. Não podemos esquecer como o Czar russo vendeu o Alasca aos Estados Unidos no século dezenove. Naquele momento, a Rússia e América eram tão distantes, que eles não representavam ameaça militar a um ao outro. Como sabemos todos nós, isto mudou subseqüentemente.

Ninguém pode saber quando ou se uma astronave será desenvolvida além da fase experimental na qual elas se encontram agora, ou se uma inovação para uma fase de fruição será possível, de forma que astronaves se tornem meios regulares de transporte humano. O mundo no qual nós vivemos é um mundo emergente, é a humanidade em movimento. Nós obscurecemos nossa visão do processo que nós como humanidade experimentamos se, ao invés de aceitarmos o mundo como ele realmente é, nós o julgamos como se fosse um mundo eternamente imutável, ou como se representasse uma fase final. Isso é que um indivíduo faz quando alguém apresenta o mundo como ruim ou como bom, como civilizado ou como bárbaro. A humanidade está em um grande processo coletivo de aprendizagem. Nós não sabemos que tipo de futuro espera pela humanidade. Nós podemos ter certeza de apenas um ponto: a humanidade do futuro parecerá bastante diferente em muitos aspectos da humanidade de hoje. $\mathrm{Eu}$ às vezes tenho o sentimento que esta é uma área de conhecimento que eu gostaria de passar às pessoas. Elas querem saber o menos possível sobre o fato de que o processo do qual eles próprios são parte desenvolverá compreensões verdadeiras ou instituições para as quais eles constroem o caminho, mas isso permanecerá desconhecido e fundamentalmente inconcebível a eles. As dificuldades que as pessoas parecem ter quando são solicitadas a observar o mundo, e assim também a sociedade humana 
- e, não menos, eles próprios - como processos em fabricação, estão possivelmente ligados com a dificuldade de ver-se a si próprios como precursores de um futuro desconhecido e, em parte, completamente inconcebível. Parece-me que eles buscam proteger-se dele deixando acadêmicos reduzirem processos a estados, ou até mesmo destilarem eternidades de um presente em curto prazo por meio de uma poderosa abstração. A fim de fazer um processo sociológico, um indivíduo tem que estar satisfeito com um ponto de partida relativamente modesto. Os processos sociais dos quais se busca construir um modelo, são não apenas não planejados, mas também inacabados. Trabalhando nos processos sociais que conduziram ao tempo presente você ajuda os que vivem a obter uma orientação melhor no mundo. Ao mesmo tempo, você prepara o caminho para gerações futuras que - auxiliadas pelo trabalho preliminar executado até o presente - podem vir a ter um conhecimento mais inclusivo e mais seguro do que nós temos agora. Nós podemos ver hoje que a tarefa que está diante de nós é trabalhar para a pacificação e unificação organizada da humanidade. Não nos deixemos desencorajar neste trabalho pelo conhecimento de que esta tarefa em nosso tempo de vida não progredirá do gozo do período experimental no qual se encontra agora. Certamente vale a pena e é altamente significante pôrse ao trabalho em um mundo inacabado que continuará além de si mesmo.

\begin{abstract}
This paper brings Elias' way of thinking concerning the interaction between the processes of technization and civilization. According to him, both are unplanned long-term processes, moving without any long-term aim. The first, the technization process, progresses as man pursues a better life. In this sense, Elias analyses the inventions and break throughs performed by man, with especial attention to to the revolution ocurred in the means of transportion, especially concerning the motorpowered vehicle and aeroplane. He points out the benefits origined from this revolution, as well as the negative aspects to the civilizing process of the mankind that ocurred parallely. Once the technological advances are used by human beings as weapons in their search for power, those with greater chances to access them will be better favoured by such advances. On the opposite side, there is the other process metioned in the text, the civilization process, which has as basic premise the self-regulation. According to Elias, this is the basic necessary condition for individual people to enhance their chances of living in harmony with others, and thus getting pleasure in life.
\end{abstract}

Key words: technization, civlization, transport, self-regulation

\title{
Referências
}

O. Billian, 1976 Beherrsche den Verkehr, Zurich, Müller.

Cambridge Modern History, 1960. Vol. 12, Cambridge, Cambridge University Press.

N. Elias, 1939/1994 The Civilising Process, Oxford, Basil Blackwell, one-volume edition, 1994.

----- 1978 What is Sociology? New York, Columbia University Press.

---- 1982 'Scientific Establishments', in N. Elias, H.G. Martins, and R. Whitley eds., Scientific Establishements and

Hierarchies (yearbook 6, Sociology of the Sciences), Dordrdcht, Reidel, 1982, pp. 3-69.

----- 1987 Involvement and Detachment, Oxford, Basil Blackwell.

---- 1992 Time: An Essay, Oxford, Blackwell [originally published in Dutch, 1974-75]. 
1992 Fire and Civilisation. London, Allen Lane The Penguin Press.

Robert Lacey, 1986 Ford: The Man and the Machine, London, Heinemann.

de Tocqueville, Alexis 1835/1961 Democracy in America Vol. I, New York, Schocken.

\section{NOTAS}

1. Para o sentido específico no qual este termo é usado aqui, veja N. Elias, O Processo Civilizador (1994 [orig. 1939]).

2. É possível que a origem da bandeira vermelha como símbolo da consciência da classe trabalhadora esteja relacionada a esta lei.

3. Durkheim provavelmente foi o primeiro em fazer uso de comparações estatísticas entre países diferentes durante vários anos para obter uma definição diagnosticamente precisa de um problema social. Ele fez isto de uma maneira exemplar em seu renomado livro $\underline{\text { Suicídio. }}$. O método comparativo é muito promissor, mas seu potencial absoluto só pode ser explorado ao máximo se for utilizado para registrar sucessões de desenvolvimento, que são processos sociais. A Tabela 2 é apresentada com este objetivo. Indica, para começar, que a eficácia dos regulamentos impostos por lei e a eficácia do autocontrole dos motoristas para a prevenção de danos e mortes devido ao tráfego de automóveis difere entre países europeus e Estados Unidos e Japão. Mostra este não ser somente o caso em qualquer momento determinado, mas também que estas diferenças variam relativamente pouco sobre um período de desenvolvimento de quase 30 anos. A Tabela 3 mostra números comparáveis para alguns países asiáticos e africanos, mas neste caso dados de séries temporais não estavam disponíveis para nenhum período significante de tempo.

4. Ou quase nenhum: em 1835 Alexis de Tocqueville, ao final da primeira parte de Democracy in América [Vol. I, New York, Schocken, 1961, pág. 521-2] fez sua subseqüentemente famosa predição que a América e Rússia seriam as forças mundiais do futuro.

5. Veja N. Elias,'Scientific Establishments', (1982: 3-69). [Também veja a discussão de Elias 'processo-redução' (Zustandreduktion) em conceitualização científico social, em $\underline{\text { What is }}$ Sociology? (1978: 111f.) - SJM]

\section{Dados completos da tradutora:}


Nome completo: Regina Negri Pagani

Filiação Institucional: UTFPR (Campus Ponta Grossa ) e UEPG (Campus Ponta Grossa)

Endereço completo para correspondência : Rua Francisco Camerino, 123

Jd Carvalho - Ponta Grossa - PR - Brasil - CEP - 84.070-240

Telefones para contato: (42) 3027-2596

e-mail: jrpagani@uol.com.br

Recebido para publicação em: 28/11/2005

Aceito para publicação em: 29/05/2006 